\title{
SOME RESULTS WITH SECONDARY BATTERIES IN TRAIN LIGHTING.
}

BY ALEXANDER 8. BROWN.

The arguments in favor of the incandescent electric light for railway passenger trains are so well understood by the members of the Institute, from their own general knowledge of the subject, as well as from papers previously presented, that it is unnecessary for me to allude to its admitted superiority over either gas, oil or candles. It is now four years since the Pennsylvania Railroad Company, appreciating the advantages of electric lighting for this purpose, began a series of experiments with the secondary battery, for the illumination of parlor cars.

I am unable to give the cost of lighting by any of the batteries referred to, as the expense appears to have been a secondary consideration compared with the necessity of securing the best system of illumination.

The first experiments made by the company were with the Faure accumulator, which was brought to this country from France in the spring or early in the summer of 1882, and put on passenger coach No. 397 in August of that year. The car was run for a few days only, but enough was learned in that time to show that the lighting of cars by secondary batteries was per fectly practicable, when a modified form of the battery conld be obtained.

During the summer of 1884 , experiments with the Blush storage batteries were commenced at the Altoona shops of the Pennsylvania Railroad, and continued through the fall and winter of that year. These experiments were made by Dr. Dudley, and proved so successful that eight parlor cars which were being constructed at that time were equipped for incandescent lighting, and put into regular service on the 1st of April, 1885. 
The Brush cells used consisted of three plates each, two negative and one positive, the amount of surface of the positive plate being equal to that of both the negatives. These plates differed from those now used, there being no paste in their composition. The negative plate shows the form of construction, and was designed to give the greatest possible amount of surface from

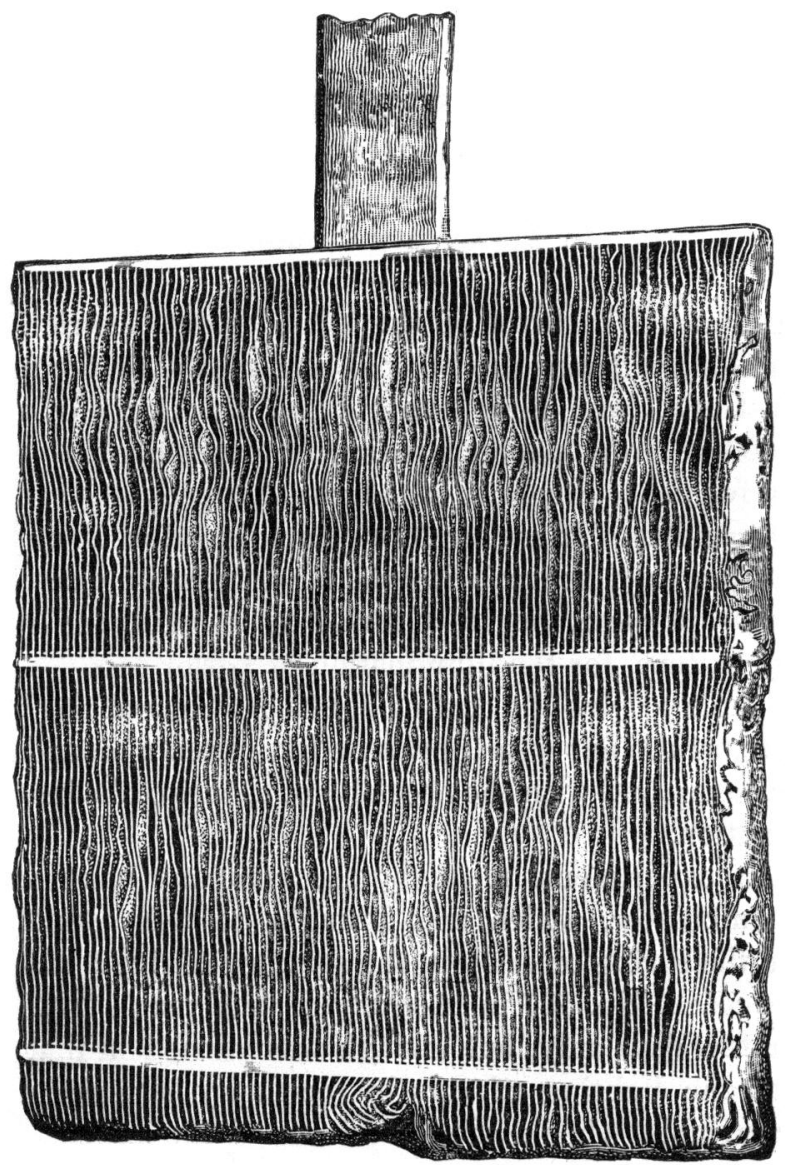

Negative Plate, BRUSh CELL.

the least weight of material. The positive plate measured $8 \times 9 \times 1$ inches, and the negative, $8 \times 9 \times \frac{1}{2}$ inches.

These batteries were rated at seventy ampere-hours, but the hard usage they received soon reduced their capacity, and at the end of a year's time the positive plates were almost entirely destroyed. In fact, I have taken plates out of the cells which had 
holes in them fully four inches in diameter, while the deposit in the bottom of the cell would be from an inch to an inch and a half in depth. The plates also had a decided tendency both to buckle and grow, and in a number of cases it was a very difficult matter to remove the plates without injury to the cell; you will understand, of course, that I allude more particularly to the positive plate. The weak points in the Brush battery were the small number of ampere-hours per pound of material-about two, I believe. There was a tendency to buckle and sulphate, and the arrangement for connecting the plates was such that there was oxidation at the junction, causing the plates to break when subject to the motion of the car. This last feature was a source of endless trouble to us, and as is usually the case, was sure to happen at a time or place where it was impossible to repair the break. While using the Brush battery the cars were wired with the battery boxes, one on each side of the car, coupled together in series, each box holding three trays, and each tray containing four cells, this giving a total of twenty-four cells to a car, or a current of forty-eight volts. The lamps used originally were of the Brush-Swan type, with small platinum loops projecting from the base, these hooking into a socket and held in place by a spiral spring, this socket fitting into another one, to which the connections to the wires were made.

After using this style for some time an improved pattern of Brush-Swan lamp was substituted; but the great drawback to this lamp was its frailty, the breakage per day often averaging four per cent. of the total number of lamps in use on the cars. These lamps required about forty-five volts and one ampere of current, and each car contained ten lamps, seven in the body, one in the smoking-room and one in each vestibule, thus using about ten amperes of current; and as the batteries were rated at seventy ampere hours, we should have obtained from six and one-half to seven hours' good light, but it was very seldom, after the batteries had been used for a short time, that we could get over five and one-half hours'. As will readily be seen, this could hardly be called economical, for to obtain five or six hours' light we were obliged to charge from fifteen to twenty hours with a Brush arc light dynamo giving a current of about ten amperes. Then taking the weight into consideration, each time the car needed charging, the trays, six in number and weighing 1,200 pounds, had to be loaded on the truck, pulled over to one side of 
the car, and the discharged trays taken out and the freshly charged ones put in their place. The remaining three were then taken around to the other side of the car and changed in the same manner. As the cars invariably stood on a double track, it was necessary to carry half the trays for some distance, over tracks, etc. Then, again, the tracks were usually full of cars, and if there was not sufficient time for them to be parted the batteries had either to be carried under the car or over the platform. Under the present system this has been done away with to a great extent, as will be explained subsequently. During the month of December, 1886, we commenced using one battery of the $7 \mathrm{~B}$ type, manufactured by the Electrical Accumulator Company. This battery was a decided improvement over those previously used, giving, as it did, nearly double the number of ampere-hours for the same weight of material. After using this battery for about a year, the positive plates began to give way, and new ones were substituted, the negatives, however, being retained, as they had not deteriorated. In fact, we are still using the negative plates of our original $7 \mathrm{~B}$ battery. This battery proved to be so satisfactory that in June, 1887, we added two more of the same type and two manufactured by the Julien Electric Company. The latter batteries were similar in size and shape to the $7 \mathrm{~B}$ type of the Accumulator Company, but did not seem to stand the hard usage so well, as they would crack instead of buckling and allow a large quantity of the paste to become loosened and fall out. It is proper to state, however, that these plates were made especially for us, to fit the cells we were using, and were not of the regular Julien type. This, no doubt, will account in a great measure for their failure to keep up to the standard of the present type of Julien batteries. After the positive plates of this battery became worthless, and not having any others to put in their place, we decided to make a kind of consolidated affair, and see how Julien negative and Accumulator positive plates would work together. The result was extremely satisfactory, and we have had no trouble with them whatever, excepting the occasional buckling of a positive plate.

During the fall of 1887 we began substituting the Accumulator batteries for the Brush batteries, and by the end of the year were using them altogether, with the exception of the two Julien I have mentioned. We, however, kept ninety-six of our best Brush cells, to be used in case of an accident to the incandescent 
dynamos, which are used to supply the current for the railroad telegraph as well as for lighting the passenger station.

After the change in batteries had been made, it was thought best to change the system of wiring the cars, so that instead of its being necessary to put batteries on each side of the car, we need only put them on one side and get the same amount of light. This was done by connecting the two boxes under the car in parallel, and substituting 23-volt Edison lamps for our 45volt Brush-Swan lamps. After doing this we found that we were able to get as many hours' light from twelve cells as we formerly did from twenty-four. Of course this change reduced the expense of lighting the cars considerably, for where we formerly had a change of battery for each car, or forty-eight cells, we now needed only twenty-four cells per car, with a few extra ones to be used in case the twelve cells would be unable to supply sufficient light for a long trip. This system of lighting proved so successful that it was decided to substitute it for gas in the remaining seven parlor cars. The wiring of these cars was commenced at the Meadow shops, near Jersey City, last September, and has just been completed. These cars are arranged for the $23 \mathrm{C}$ type of the Accumulator Company's battery and $19 \mathrm{~B}$ type of the Julien battery. The battery boxes under the cars are larger than the old style, and contain four trays or sixteen cells, the lamps we used taking twenty-three volts of current. Ohanges were also made the first of the year in the system of charging, and the batteries are now charged from an incandescent dynamo instead of an arc, thus enabling the batteries to be charged with any amount of current desired. In connection with this description of the four years' work of the Pennsylvania Railroad, I would like to add something in regard to the electric lighting of the Chicago limited express.

In 1887 the Pullman Palace Car Company commenced using the electric light on one of three trains of the New York and Chicago limited express, and the charging of the batteries at Jersey City was given into the hands of the Pennsylvania Railroad Company. The batteries used were the $7 \mathrm{~B}$ type of the Electrical Accumulator Company, thirty cells to a car, and usually there are six cars in the train. These batteries would furnish enough light for one trip, and each time the train arrived at either terminus it was necessary to replace them with freshly charged cells. This was not objectionable at Chicago, for the 
train arrived there in the morning, so that they could be charged during the day; but in Jersey City, where the train did not arrive until evening, the work was very difficult on account of the dynamo being in use for other purposes. After this one train had been running a short time, another one was fitted up, $19 \mathrm{~B}$ type of Julien battery being used. It was thought that this would give us a chance to see which was the better of the two batteries, but they both worked very well, considering the treatment they received. After Mr. Bauer became connected with the Pullman Company he did away with charging the batteries at the ends of the line, and introduced a Brotherhood engine and Eickemeyer dynamo in the baggage car of each train, in order that the batteries might be charged in transit. When the train leaves Jersey City the baggage car is on the rear, and consequently no charging is done until it leaves Philadelphia, where the train is reversed, bringing the baggage car next to the locomotive. The batteries are charged continuously until the train reaches Chicago, and the same practice is continued on the return trip. The steam for driving the Brotherhood engine is taken from the locomotive boiler, and the exhaust is used for heating the train.

So far as the Pennsylvania Railroad is concerned, the electric lighting of passenger trains may be considered an assured success, and leading, as it does, to the abolition of kerosene lamps, and incidentally encouraging the adoption of steam heating, the safety and comfort of the passengers are certainly increased.

\section{DISCUSSION.}

Mr. Geo. B. Prescott, Jr.:-I think Mr. Brown's paper is very interesting, and I am sure the Pennsylvania Railroad Company deserves a great deal of credit for making the experiments. I think that these tests have demonstrated one thing very positively, and that is, that an accumulator made entirely on the Planté principle, without active material applied according to the Faure method, is an impracticable battery for commercial purposes. The improvement in storage batteries of late years, and particularly in the past year, has been very great, and the practical use of batteries shows that unless they are handled as if they were a delicate piece of machinery they will never give very satisfactory results. Wherever accumulators have been properly installed and have been treated as if they were worthy 
of being properly cared for, they have been very reliable, and they certainly fulfil certain conditions that no other electrical machinery does to-day.

The improvements in the use of electrical accumulators are not confined to the cells themselves. No matter how good an accumulator may be, if it is not properly installed with suitable apparatus for regulating both the charge and discharge, it will never give satisfactory results. If the accumulator is overcharged, the paste is peroxidized to such a high degree that it becomes a very fine powder, without sufficient consistency to hold together, and it gradually deposits in the bottom of the jar. That comes from overcharging, and yet it was only a year ago that it was thought that overcharging improved accumulators. We know now also that if the cells are allowed to overdischarge they become very heavily sulphated, and the longer they stand in a discharged state the more dense this sulphate becomes, and then, if the charging is commenced at what would otherwise be the normal rate, the gas seems to be developed within the interstices of the pellets, and as the sulphate is not in a condition to take up the oxygen it is liberated, and the result is that these pellets are forced right off the perforations in chunks, so to speak. If, however, the cells are charged and discharged within certain limits, which can be determined for every size of cell, and if any short circuits that may occur through accident or other cause are removed at once, the accumulator, to-day, is a perfectly reliable piece of apparatus.

Mr. C. O. Mailloux :-I would like to ask Mr. Brown whether the charging of accumulators at either terminus of the road has been definitely abandoned in favor of the system of charging on the train. I ask this question because I know that on some roads there is a very great and decided objection to deriving the energy for charging the batteries from the locomotive; that is particularly the case with the Boston and Albany Railroad. I once had occasion to discuss the matter with the President of the Company, and he would not entertain at all any project for charging the batteries on the road, for the reason, he said, that they needed all the energy, whether they used it in the form of steam or derived it from the axle-they needed it all for propelling the train itself, their object being to make the shortest time.

I would like to ask another question about the latest modifica- 
tions. Mr. Brown said that a smaller battery would do the work. I do not exactly understand this, unless he used lamps of higher efticiency, giving the same candle power with a smaller expenditure of energy. I would like to have him elucidate that matter for us.

Mr. Alex. S. Brown:-Mr. President, in regard to the charging of batteries on a car or at the terminus, you will understand that the Pennsylvania Railroad still charge at Jersey City. It was the Pullman Company I alluded to; they have done away altogether with the charging at either terminus, with the exception of keeping a few spare cells both at Jersey City and Chicago, so that in case the train arrives in Jersey City in the evening, and anything is the matter with the cells, or the trays, we simply have a good tray ready to put in its place.

In regard to the lamps. I spoke of using a battery with a less number of cells. When we were using 24 cells of the accumulator battery we would get about 14 or 15 hours' light, using the Brush-Swan lamps of 45 volts. When we changed and commenced using 23 or 24 volt lamps and 12 cells we got about $\tau$ hours' light. You see it was really about the same thing, but we found it was easier to change the cars a little bit oftener and use a less number of trays, and at the same time we had to keep a less number of cells on hand in the battery-room. We found it more economical in both ways to work in that manner.

Mr. Wm. H. Peirce: I would like to ask the weight of those cells per lamp, and if there have ever been any experiments tending to show the quantity of steam used.

Mr. Brown: I really cannot say very much about the Pullman work, because I am not connected with that in any way now. I do not know just how much steam they require. But in regard to the other matter-the lamps -I supposed it to be a 16-candle power lamp; that is what they are held up to. Of course they may fall off a little, but when the battery is properly charged, they seem to hold right up. We have no method of testing in Jersey City, but that is what they are rated at. The weight of a cell is about 50 pounds.

Mr. Peirce:-That feeds how many lamps?

Mr. Brown:-We use 10 lamps on a car. The weight of battery on a car is 600 pounds ; we use 12 cells.

Mr. Prescott :-Mr. Mailloux referred to the objection that he had heard made by some railroad company to making use of 
steam for driving the dynamo. I think that objection is not very well founded. We all know that the use of steam for heating cars is being universally adopted, and some steam could be used for driving a small engine to run the dynamo and the exhaust used for heating the car. On the other hand, the amount of steam required to drive the small engine is such an almost infinitesimal part of the total amount of steam generated in a locomotive boiler that it hardly need be taken into account.

Prof. Edward L. Nichols:-I should like to inquire of the author of this paper whether he can tell us anything about the average life of accumulator cells used in railway service as compared with the life of the same type of cells doing the same amount of work when stationary. I have had this question asked me many times and have looked in vain for definite information concerning it.

Mr. BRown:--I am sorry that I cannot answer that question, because I have never had any experience with stationary cells. $\mathrm{My}$ experience has been confined entirely to railroad cells. We calculate our positive plates will last about a year. They are in use almost all the time. Of course they have a great deal more usage than the stationary cells, although I do not think that the motion of the train does them any harm at all. We do not find that the batteries splash any. Of course there is some little motion, but being in the center of cars about 65 feet in length, the motion there is very little, so I do not think that does any harm.

The President (Prof. Elihu Thomson):-Mr. Vansize can probably give us some information on the point just raised.

Mr. W. B. Vansize:-As to the President's suggestion, I would say that the details under consideration come more within the line of practical every day contact with the work, with which I have had very little experience. I have heard it suggested, however, that there might be some advantage in the motion on a railroad car, because the agitation of the liquid would make a more even dispersion; that is, the specific gravity would be more equal at all points of the cell, and while there might be some detrimental results from the shaking to which the material was subjected, the difficulty in that direction would be perhaps more than made up by the uniformity of the electrolyte. I do not know that any tests have ever been made to determine this question. 
Prof. Nichols asked the relative duration of a cell whose life was spent upon a car as compared with that used in stationary work. I do not know that it has been determined; but the general opinion is, so far as my experience goes, that the railway cell has a somewhat abbreviated life. The varied attention which the two classes of cells receive would also determine that result to a certain extent. A cell in use on a railroad train would naturally receive a little more careful attention than a stationary cell, unless a system of inspection was in use in connection with the latter.

Mr. Mallloux :-I may be able to give some information in that direction by reference to the experience on street car lines. The storage battery is never put to a more crucial test than it undergoes upon a street car. My own experience and observation lead me to believe that a battery submitted to the same rates of charge and discharge would last longer on a car than in stationary places. I have seen the same battery when used in stationary work and when in use on street cars and also in railroad cars. In street cars the work was always necessarily much more severe. There were times when the battery might have to withstand a current rate of from 50 to 100 amperes; while in stationary work the same battery would never have a current rate exceeding perhaps 25 to 35 amperes; and yet, even under those very trying conditions, I have known of batteries, the positive plates of which were still quite good after fifteen months' use-almost daily use. For a long time the plates were used daily at least once, and sometimes charged twice a day, and yet after fifteen months' use the active matter was not sufficiently gone; in other words, the plates (of course I refer to the positive plates, because the negatives were nearly as good as ever) were still perfect enough to do good work, and this would show that there must be something in the vibration or the shaking of the cells which counterbalances somewhat the hard usage which it receives in the way of excessive rates of either charge or discharge. The particular battery which I refer to was once discharged on short circuit while on the road by the bursting of an armature. One of the cars was going down the steep grade in the upper part of Madison Avenue and the man thought it would be splendid fun to coast down hill. I suppose he must have developed a speed of 20 miles or more, and one of the armature bands ruptured, and being only a street car man he did not seem to think that that made much difference-perhaps 
he did not notice it. When he got to the bottom of the grade he very innocently turned the switch to put on the current. The car did not seem to move very fast, and he was made conscious that something had happened by the conductor telling him that something was smoking. The trap door was removed, and he found that one of the motors seemed to be burned up. So the car was brought back. It was an experimental car, and upon investigation I found that the current rate of discharge had been sufficient to burn up one of the connecting strips by which the circuit was closed from cell to cell. In other words, one of these strips had acted as a fusible plug, and from its area of section I concluded that the current rate must have exceeded 300 or 400 amperes. I also found that the field wire, which was $4 \frac{1}{2} \mathrm{~B} . \& \mathrm{~S}$. gauge wire, had become heated sufficiently to char the insulation almost the whole length, so I concluded that it must have had a fair rate of discharge. I naturally thought that the batteries would be ruined, but I had them taken out and cleaned, and to my great surprise I found that while there was some active matter in the bottom of the cells, it was not at all, in quantity, what I expected. In fact, it was so little that I did not know how much of it was due to that immediate circumstance and how much was due to previous wear and tear. At any rate, the batteries were put into the same car, except two of them, which were ruined by the melted lead flowing out where the circuit was broken by the melting out of the safety plug. Shortly afterwards the same battery was again short-circuited by some accident which occurred in the station itself while making connection with the machinery. It was short-circuited in such a way that only the field wire of one of the motors was put across the terminals, and the connection seemed to be better this time, and we did not know of it until we heard a violent hissing noise. I jumped on the car-it was one o'clock at night-and struck a light, and noticed that the solution was boiling in several of the cells; so I very quickly opened the circuit and we found that the battery had been discharging at an excessive rate. Again I thought the cells might be ruined, but I had them washed and cleaned, and they did a good deal of work after that. This goes to show that in the first place storage batteries will stand a much higher rate than generally supposed, with comparative impunity, and it corroborates perhaps the belief which I have that when once the active matter of a storage battery has become thoroughly recep 
tive by a proper course of treatment either originally in the making or construction of the battery or subsequently in the nursing or treatment of it, that you can do with it a great deal that would ordinarily be considered as abuse.

The President :-As we have another paper on the storage battery, perhaps it would be well to have the paper read before continuing this discussion. We have with us Dr. Duncan and he will give us a paper on the inherent defects of lead storage batteries-a subject which cannot fail to be of great interest. 